\title{
Transforming Single-Family Neighborhoods: A Climate Action and Social Equity Mandate
}

\author{
RICHARD MOHLER \\ University of Washington
}

Keywords: single-family zoning, climate action, social equity, racial exclusion, design advocacy

In many fast-growing cities around the country, up to threequarters of the land zoned for residential use is reserved for detached, single-family dwellings at suburban densities. This is both a climate justice and racial justice issue as it has the doubly negative impact of artificially constraining housing supply and driving up costs, forcing many lower and middle income families farther away from job centers and imposing on them long, costly, and carbon-intensive commutes. Single-family zoning was also used as an explicit tool to segregate the U.S. by race starting in the 1920 s and, in the process, denied countless people of color access to homeownership, the most powerful wealth-building tool available to U.S. families. This is a significant factor in the stark racial disparities in household wealth that we see today.

This paper outlines the findings of a nationally cited report on single-family zoning released by the Seattle Planning Commission, which advises the City Council and Mayor on land use and housing policy and of which the author is a member. It also reviews a collaboration between the commission and a graduate research-based architectural design studio and seminar co-taught by the author. This collaboration re-envisions urban, single-family neighborhoods to be more equitable, sustainable and livable while engaging students in a national policy dialogue in the process. The results of the studio will advance the commission's efforts to advise Seattle's elected officials in revising public policy to be more aligned with the city's climate and racial justice goals.

\section{INTRODUCTION}

Single-family zoning is among the most controversial social equity and sustainability challenges in the U.S. as, for many, the detached single-family home embodies the American Dream. This paper will review the origins of single-family zoning and its environmental and social equity impacts in Seattle and other fast growing U.S. cities. It relies in part on research conducted by the Seattle Planning Commission, of which I am a member, although I speak only myself on these pages. It will note how the inequities of single family zoning have been amplified and exacerbated by the current pandemic and will conclude with a discussion of student work from a graduate architecture research design studio and seminar I taught in winter quarter, 2020 at the University of Washington in collaboration with the Seattle Planning Commission.

Nowhere is growth and change met with more resistance than in single-family neighborhoods throughout the U.S. Expressed concerns of single-family homeowners include the potential loss of existing tree canopy, the reduction of available onstreet parking and the unleashing of a wave of speculative development that could lead to displacement and the loss of so-called livability ${ }^{1}$. What these positions fail to acknowledge, however, is that single-family zoning artificially constrains the supply of housing within cities. While new development can and often does physically displace people from their homes through demolition, far more are displaced economically as their rents rise beyond what they can afford due largely to housing demand not being adequately met by housing supply. ${ }^{2}$ This condition pushes households further away from employment, education, health care and other services while forcing long commutes to auto dependent locations with lower rents but higher transportation costs due to the increased reliance on car ownership. In the process, this dramatically increases per capita vehicle miles travelled and resulting carbon emissions while a greater loss of tree canopy is incurred as new suburban green field development replaces what could have been urban infill development that leverages existing municipal infrastructure.

Despite being the northernmost major city in the continental U.S., Seattle has a temperate maritime climate which reduces the heating and cooling load on buildings relative to many other U.S. cities. ${ }^{3}$ Since the early 20th century, Seattle has relied almost exclusively on hydroelectric power which, while raising other environmental concerns, has virtually no direct carbon emissions in contrast to coal or natural gas fired power plants. However, the city also has among the highest per-capita rates of car ownership in the U.S. ${ }^{4}$ As a result, automobiles account for roughly half of Seattle's direct carbon emissions and much of this can be attributed to the city's single-family zoning policies which thwart the development of compact, walkable communities with robust access to transit. ${ }^{5}$ 


\section{“NEIGHBORHOODS FOR ALL" REPORT}

While single family zoning's contribution to carbon emissions and climate change is troubling, the social inequities that single-family zoning engenders are more disconcerting still. In response, the Seattle Planning Commission began to examine Seattle's single-family zoning policy through a social equity lens in 2017. The commission consists of sixteen volunteer members who live in neighborhoods throughout the city and provide experience and expertise ranging from architecture and urban planning to mobility, affordable housing development, public health policy and the social equity dimensions of climate change. ${ }^{6}$ Commissioners are appointed by the city council and mayor to advise them on issues related to land use, housing and transportation. While the commission's primary charge is to evaluate and comment on policy proposals from various city departments, it also conducts independent, policy-based research projects that elected officials and city staff may be unable or unwilling to pursue. The commission's examination of Seattle's single-family zoning is an example of this.

In late 2018, the commission released a report titled "Neighborhoods for All - Expanding Opportunity in Seattle's Single Family Zones" of which I am a co-author." The report outlines the history of single-family zoning in Seattle and includes a series of observations and recommended strategies to address the social inequities of single-family zoning. The report outlines Seattle's meteoric rise in housing costs and notes that the principal reason for this rise is that, while more housing has been built over the past decade in Seattle than in most comparably sized cities, it has failed to keep pace with the unprecedented job growth that has increased Seattle's population by nearly $30 \%$ during that time. ${ }^{8}$

This misalignment between job growth and housing production has existed since the mid-1980's when Seattle emerged from a fifteen year period of economic and population decline due to the so-called Boeing Bust. ${ }^{9}$ Boeing, the world's largest manufacturer of commercial and military aircraft and the region's largest employer, saw a steep decline in aircraft demand due the energy crisis and cuts in military spending in 1970 leading to massive layoffs and a loss of roughly 15\% of Seattle's population. In 1985 Microsoft, headquartered just east of Seattle, launched Seattle's tech economy with its Windows operating system which, combined with a national interest in Seattle's grunge music scene, coffee culture and striking natural setting, encouraged population growth. Due to zoning constraints and the relatively low cost of housing at the time, however, the housing market was slow to respond to this rebound. The more recent resurgence of Boeing and the growth of Microsoft and other tech companies, most notably Amazon, has fueled an escalation in job and population growth. However, between 2016 and today less than half the amount of housing needed to accommodate this growth has been constructed. ${ }^{10}$
The Planning Commission's report also reviews Seattle's zoning history, which mirrors those of cities around the country. Seattle's original zoning ordinance was enacted in 1923 and it differed from the building codes that preceded it by focusing on building use, as opposed to building safety. The 1923 code also introduced the widespread mandate for detached, single-family homes by designating roughly half of the city's developable land exclusively for this building type. ${ }^{11}$ From the 1950's to the early 1980's, Seattle gradually expanded singlefamily zoning throughout the city by downzoning areas that had previously allowed duplexes and triplexes to exclusively single-family use. ${ }^{12}$

In response to the 1990 adoption of the Washington State Growth Management Act, which is designed to contain sprawl by mandating increased development capacity in existing cities and towns, Seattle introduced two significant zoning changes in 1994. First, the city allowed accessory dwelling units, or ADU's, within or attached to single-family dwellings. Second, the city established the urban village growth strategy which locates growth close to existing transit in urban villages at three scales - the most dense being Urban Centers followed by Hub Urban Villages and the least dense, Residential Urban Villages located within neighborhood commercial districts. ${ }^{13}$ By locating growth close to frequent transit, urban villages have had the positive impact of making Seattle one of the few U.S. cities with increasing per capita transit ridership. However, the urban village growth strategy was also used as a negotiating tool by single-family homeowners in the early 1990's to ensure that their neighborhoods would not be impacted by future growth. This perceived agreement continues to beleaguer the city's discussions related to single-family zoning reform today.

As with virtually every U.S. city, Seattle's growth has been shaped by a history of systematic, government-led racial segregation that denied people of color access to home ownership, the most powerful wealth building tool available to U.S. households. ${ }^{14}$ Racially exclusionary zoning and restrictive covenants prevented households of color from living in most Seattle neighborhoods forcing them instead into less desirable areas adjacent to or within industrial zones and in neighborhoods lacking schools, parks, commercial services and quality housing stock. While Black people bore the brunt, Asian, Jewish, Hispanic and Indigenous households were sometimes excluded as well. To mitigate the impacts of the Great Depression the Federal Government created the Home Owners' Loan Corporation (HOLC) in 1933 to refinance home mortgages that were then in default to prevent foreclosure. ${ }^{15}$ HOLC loans made home ownership more accessible as they were amortized loans with lower interest rates than the previously existing interest-only loans in which the principal was due in full at the end of loan.

However, HOLC is generally cited as institutionalizing the segregationist practice of redlining, which entails color coding 
neighborhoods by level of investment risk. ${ }^{16}$ Lending regulators produced maps of Seattle, and virtually every city in the country, where red denoted "hazardous", yellow "definitely declining", blue "still desirable" and green "best". The "hazardous" areas were the same neighborhoods, such as Seattle's Central District, where households of color were forced to reside through racially exclusionary zoning and restrictive covenants. Households in these neighborhoods consequently found it difficult if not impossible to gain access to mortgage financing and the wealth-building capacity of home ownership. This limited their financial ability to move from the neighborhood even after racially exclusionary zoning and restrictive covenants were lifted.

Single-family zoning itself played a role in Seattle's segregationist strategy. While the city was drafting its 1923 zoning ordinance it hired Harlan Bartholomew, considered by some to be the father of U.S. comprehensive planning, as its consultant. When planned segregation through racially restrictive zoning was deemed illegal by the Supreme Court in 1917, Bartholomew proposed using single-family zoning itself to achieve the same ends. While drafting the original St. Louis zoning code in 1919 as that city's first planning engineer he stated that a goal of the ordinance was to "preserv[e] the more desirable residential neighborhoods" and to block movement into "finer residential districts... by colored people."17 Bartholomew would later consult with cities around the country regarding their zoning codes and would advance the same goal through single-family zoning. The principle was simple. By making housing artificially expensive through single family zoning's mandate of minimum lot sizes and detached structures, it would segregate cities by class and race.

Today, a staggering 75\% of Seattle's residentially zoned land is reserved for detached, single family homes at suburban densities while a mere $25 \%$ of its residentially zoned land allows for multi-family structures. ${ }^{18}$ This is a condition found in fast growing cities throughout the U.S. While only 15\% of residential zones in New York's five boroughs are zoned single-family the numbers are $70 \%$ in Minneapolis, 75\% in Los Angeles, $77 \%$ in Portland, OR, $84 \%$ in Charlotte, N.C. and 94\% in San Jose, CA. ${ }^{19}$ As mentioned above, this has the doubly negative impact of artificially constraining housing supply and driving up costs, forcing families farther away from job centers and imposing on them long, costly and carbon-intensive commutes.

Not coincidentally, the zoning maps in these cities closely approximate the HOLC redlining maps with previously "red" areas now zoned for multi-family and "blue" and "green" areas zoned single-family. Because these cities have directed nearly all their recent growth to those "red" and "yellow" areas while putting single-family zones off-limits, many households of color have been displaced from their communities to locations outside the city and many more are at risk. ${ }^{20} \mathrm{~A}$ legacy of these polices in Seattle is that most publically funded amenities such as parks, schools, playgrounds and community centers are located within single-family zones while most subsidized affordable housing, which could most benefit from these amenities, is located further away in multi-family zones. ${ }^{21}$

Today, many Seattle single-family homeowners fear that changes to so-called neighborhood character will result from changes to land use legislation to address these inequities. However, single-family neighborhoods in Seattle and around the country are already changing as modest existing homes are demolished and replaced with new single-family structures three to four times the size. ${ }^{22}$ At the same time, many Seattle single-family neighborhoods have actually lost population despite the city's dramatic growth. ${ }^{23}$ This is mostly due to changes in household demographics, but, the current trajectory in Seattle, and cities around the country, is fewer people living in more floor area which has a devastatingly negative impact on both housing affordability and sustainability.

An outcome of the proliferation of single-family zoning in Seattle is that $95 \%$ of the city's growth in the last decade has been constrained to the $25 \%$ of its residentially zoned land that allows multi-family structures. A mere $5 \%$ of the city's growth has occurred in the $75 \%$ of the city's residentially zoned land reserved for detached single family homes. ${ }^{24}$ This is simply not an equitable distribution of the burdens of growth. More importantly, this has yielded a dichotomy of housing types in which $43 \%$ of the city's housing stock consists of detached single-family dwellings and nearly $40 \%$ consists of small apartments in large multifamily buildings with very little in between. ${ }^{25}$ This dichotomy has yielded an inequitable condidition in which those wealthy enough to afford a detached house with porches and private yards also have the best access to publicly funded parks, schools and playgrounds while most others live in large apartment buildings on arterial streets with elevators, double loaded corridors and little if any access to open space. This inequity is problematic under any circumstances but especially so during a stay-at-home pandemic such as the one we are now experiencing.

What is lacking are so-called missing middle housing types including duplexes, triplexes, courtyard housing and small apartment buildings, the very building types that Seattle zoned nearly out of existence with its 1923 zoning code and the steady expansion of single-family zoning that followed. ${ }^{26}$ These ground related or nearly ground related housing types offer much needed housing quantity and variety for a diversity of households while providing access to private and/or shared on-site open space. They would also offer the same access to publicly funded amenities that single-family homeowners currently enjoy and would expand opportunities for affordable homeownership and the wealth-building capacity it provides. 


\section{“NEIGHBORHOODS FOR ALL" RESEARCH DESIGN STUDIO AND SEMINAR}

In 2017 the University of Washington launched a substantially revised Master of Architecture curriculum for the first time in nearly three decades. This removed the requirement that every student complete a thesis and offered two research studios and companion seminars in the final two quarters of the program as an alternative.

In winter quarter, 2020 I taught, with Seattle architect and colleague Brad Khouri, the inaugural version of the architecture research studio and seminar. Entitled "Neighborhoods for All" the coursework was taught in collaboration with the Seattle Planning Commission focused on expanding and evolving the commission's work as outlined in its report of the same title.

The seminar informed the studio work by delving into the racist history of Seattle's single family zoning policy, its inherent inequities and the ways in which it thwarts the creation of compact, walkable and sustainable communities. It explored strategies being employed in other cities including Minneapolis and Portland to address single-family zoning policies in those cities. Community land trusts and limited equity cooperatives were presented as alternative financing strategies that could address displacement concerns and expand opportunities for affordable home ownership.

A goal of the seminar was to engage students in a national conversation regarding the paradox of single-family zoning's racist legacy yet the strong support it receives from homeowners in cities such as Seattle that claim to be politically progressive. Several guests joined the seminar both in person and via Zoom (before the platform became the new normal in response to the pandemic). Guests included, among others, housing analyst and advocate Michael Andersen of the Sightline Institute and Eli Spevak, a community developer and single-family code hacker both based in Portland and Lisa Bender, President of the Minneapolis City Council, who led the effort to eliminate single family zoning in that city .
The studio intentions were to leverage student proposals to both visualize an increase in the quantity and variety of housing opportunities in single-family zones and to suggest potential land use strategies to bring this to fruition. Together with the commission's report, the goal was to influence single-family zoning policy in the next major update to Seattle's comprehensive plan.

The studio asked students to consider the following key questions:

1. What is most valued in Seattle's single-family neighborhoods?

\section{How does this vary between neighborhoods?}

3. How can this value be retained or even enhanced while increasing housing quantity and variety?

4. How can displacement be minimized, especially in lower income communities and communities of color?

5. How can opportunities for home ownership be expanded, especially in lower income communities and communities of color?

The studio of 19 students worked in teams of three or four to develop strategies for infill development in six Seattle single-family neighborhoods as an alternative to the current "one-size-fits-all" mandate of single family zoning. Neighborhoods were selected to provide a diversity of contexts with respect to population demographics, topography, vegetation and tree canopy, lot size, age of neighborhood and housing stock, walkability and access to transit, open space and commercial amenities. Student teams prepared an indepth analysis of each neighborhood's history, demographics and conditions that have impacted the community in the past or may do so in the future. While the constraints of the ten week quarter limited the engagement with residents of each neighborhood, students had access to a substantial city data
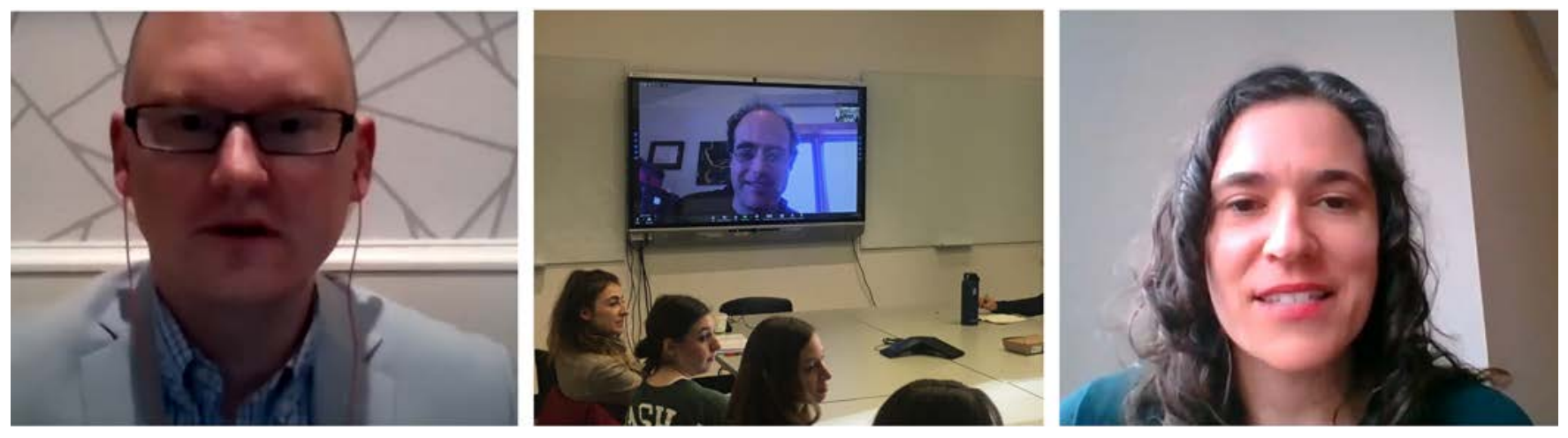

Figure 1. Seminar guests joined remotely including (from left to right): Michael Andersen, Sightline Institute; Eli Spevak, Orange Splot Development; Lisa Bender, Minneapolis City Council. Image credit.UW Neighborhoods for All Studio/Seminar 

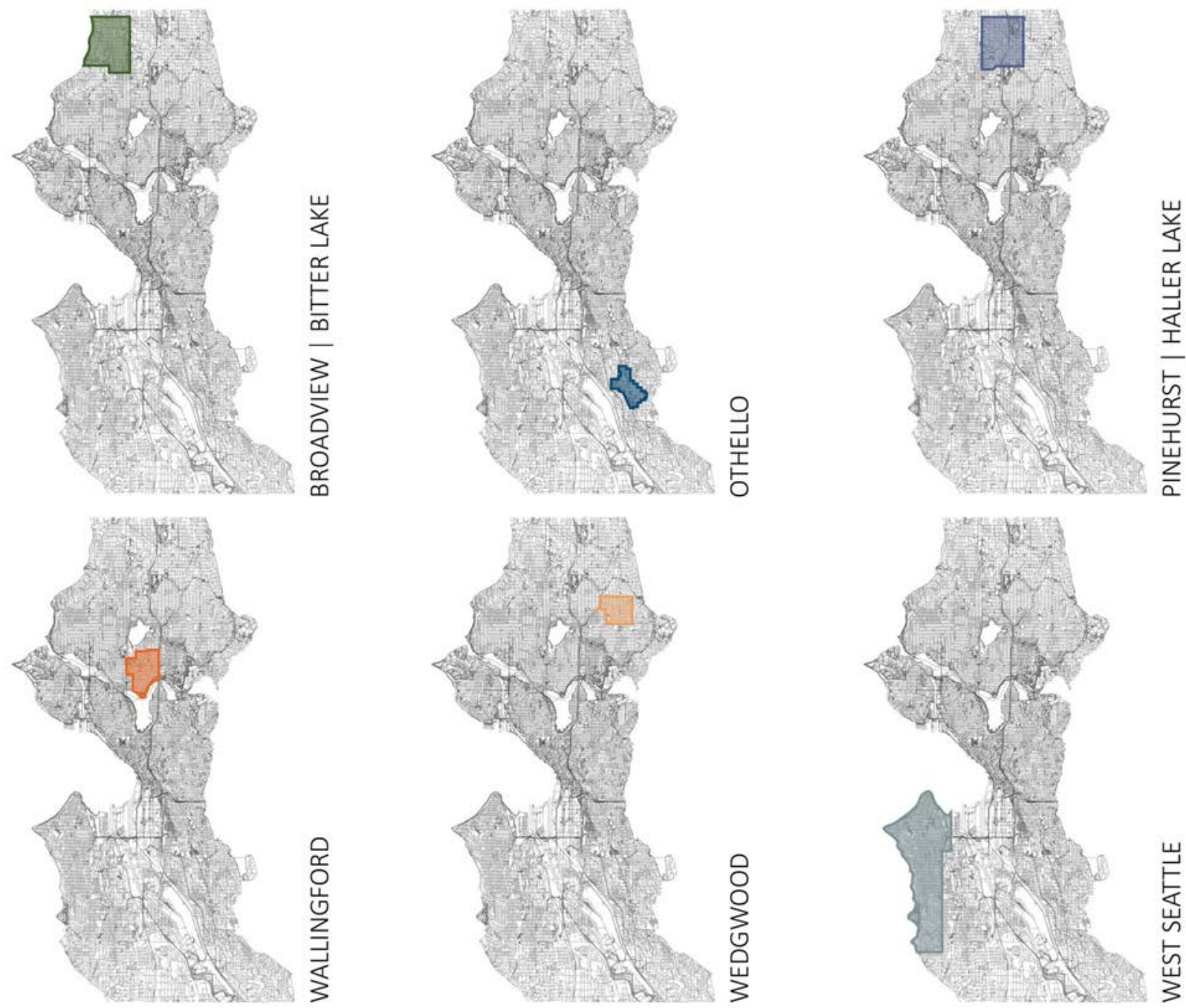

Figure 2. Six Seattle neighborhoods were studied representing a range of topography, demographics, walkability, transit access and other factors. Image credit. UW Neighborhoods for All Studio/Seminar

base of neighborhood information and community plans. Each team was also assigned a neighborhood "ambassador" who, while providing only one person's insight, were selected for their deep knowledge of and involvement in the community.

Students were provided with a hypothetical land use code matrix employing a floor area ratio (FAR) incentive system to encourage a larger number of smaller dwelling units in contrast to the large single-family homes being built today. The matrix would establish a given level of development capacity, or FAR, depending upon the number of housing units proposed on a given lot type. For example, a proposal with six dwelling units on a corner lot would be allowed more FAR than a mid-block lot of the same size with only three units. Particular emphasis was placed on expanding opportunities for affordable home ownership, especially in lower income neighborhoods and communities of color.

\section{REPRESENTATIVE NEIGHBORHOODS AND PROJECTS}

Bitter Lake in northwest Seattle is a diverse and relatively affordable neighborhood consisting of relatively large lots with modest houses on long blocks with alleys and relatively level terrain. The combination of long blocks, limited sidewalks and a lack of neighborhood commercial destinations hampers neighborhood walkability. In response, the student team proposed a strategy of "extend, activate and connect" to extend commercial destinations into the neighborhood, activate the alleys with new housing types and connect streets through the long blocks with pedestrian through block connections. To advance housing affordability, existing housing stock is retained and back yard infill development is incentivized with the exception of new block end development

With a team developed neighborhood and block strategy in place, students worked individually in advancing proposals 


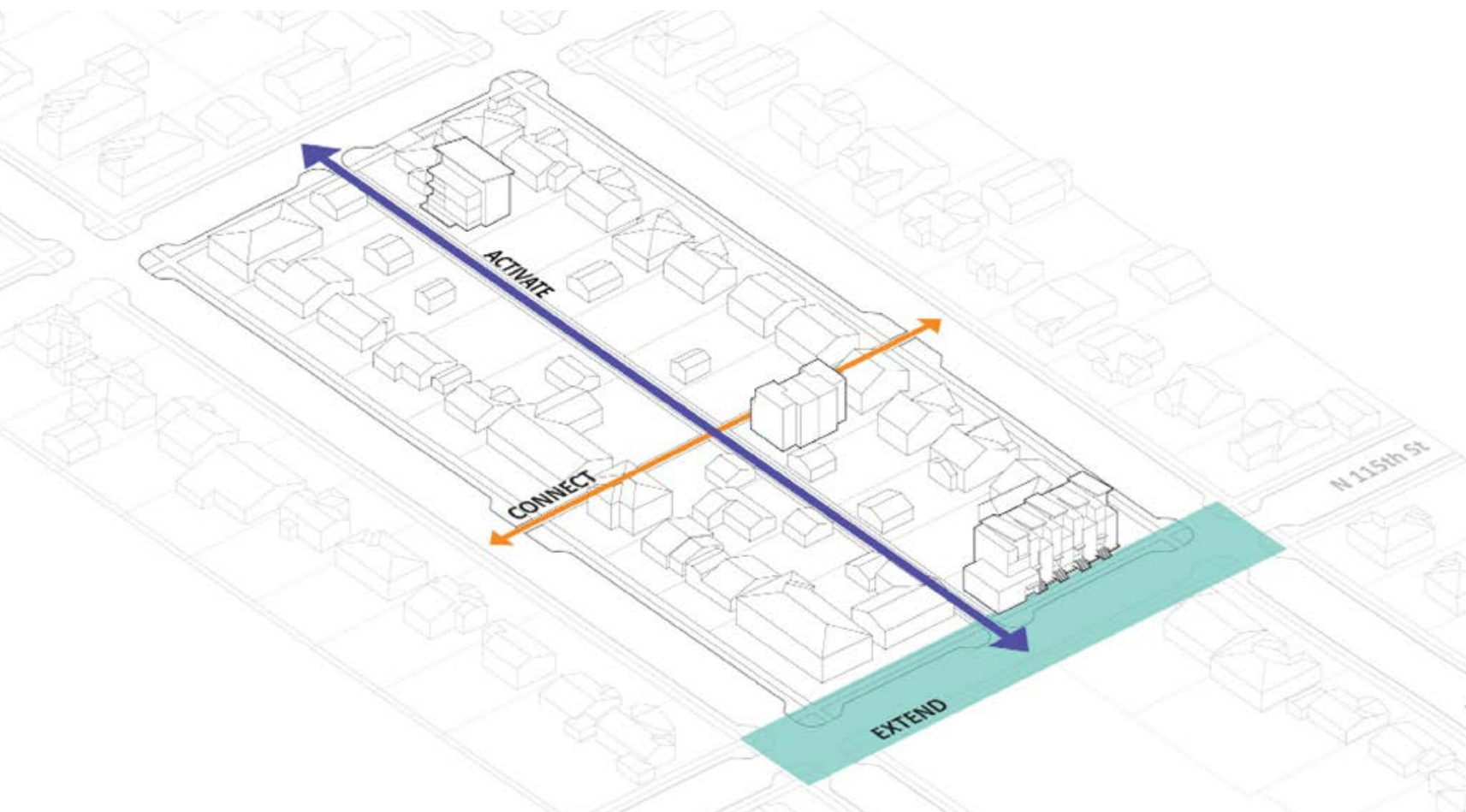

Figure 3. In Bitter Lake block end development extends the nearby commercial street into the community, the alley is activated with new housing and the long blocks are connected with mid-block connections lined with new housing. Image credit.Paige Collins, Nolan Nolan Higa, Benny Yeo
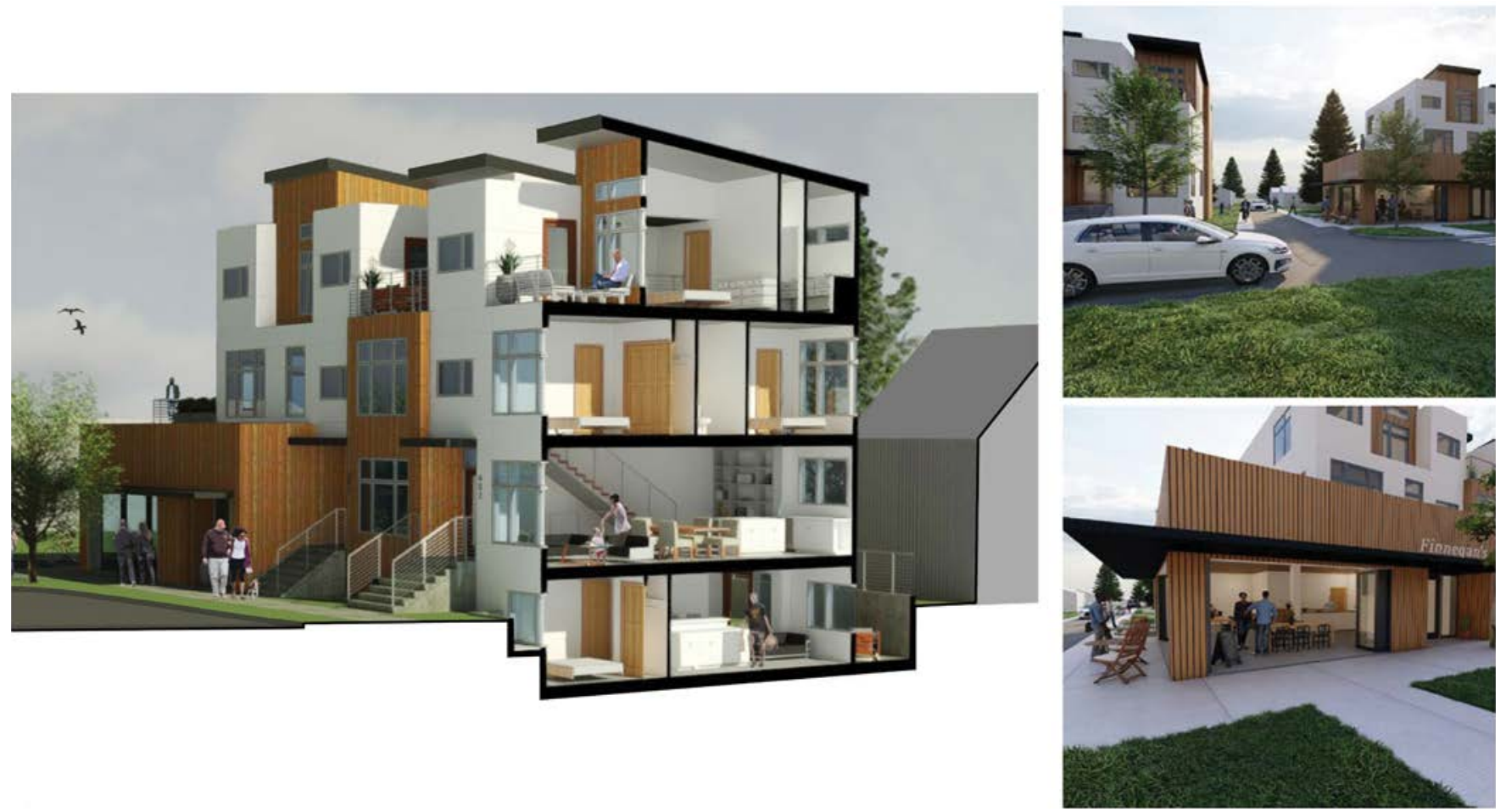

Figure 4. Block end development includes row houses.with ADU's below and a cafe that connects the street with the activated alley Image credit. Paige Collins 

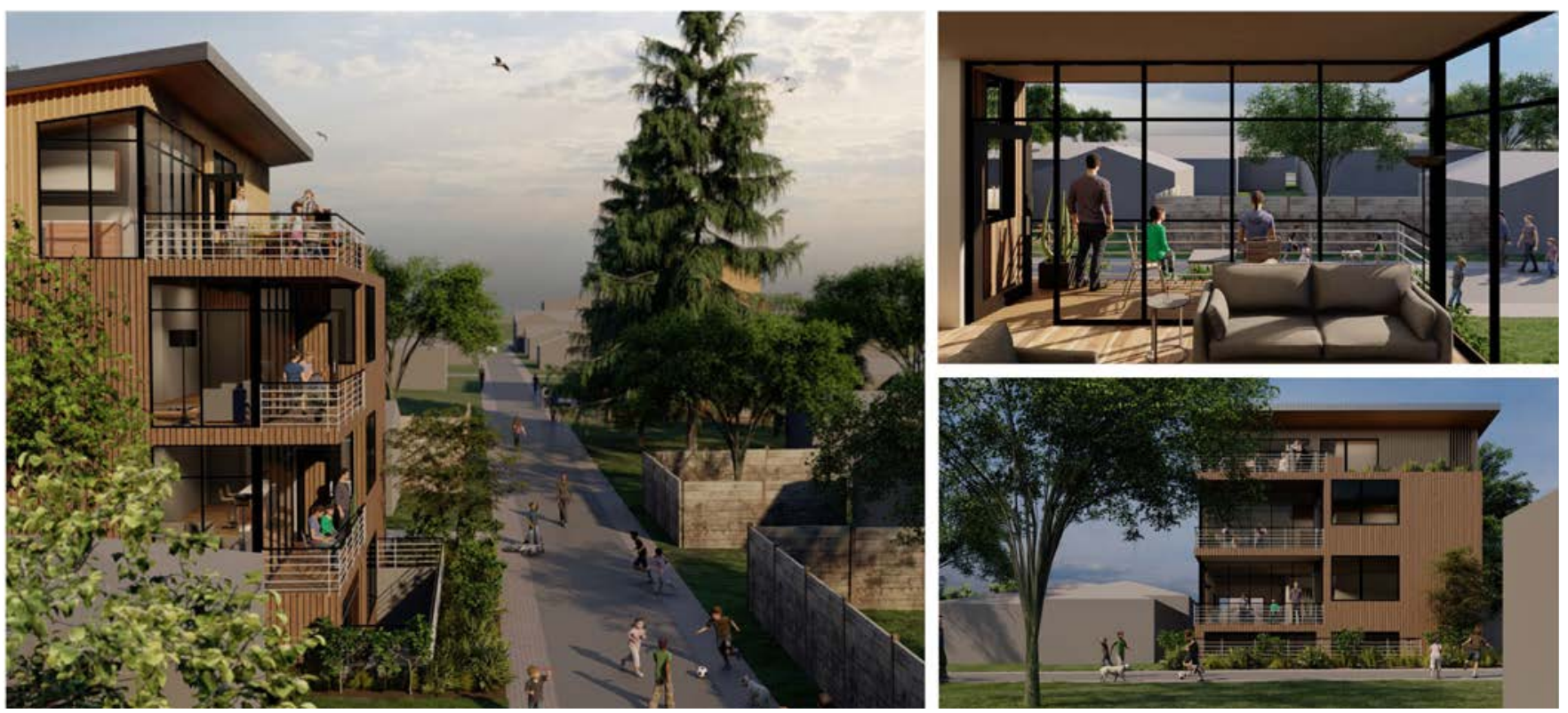

Figure 5. Stacked two-bedroom flats with balconies activate the alley. Image credit.Benny Yeo
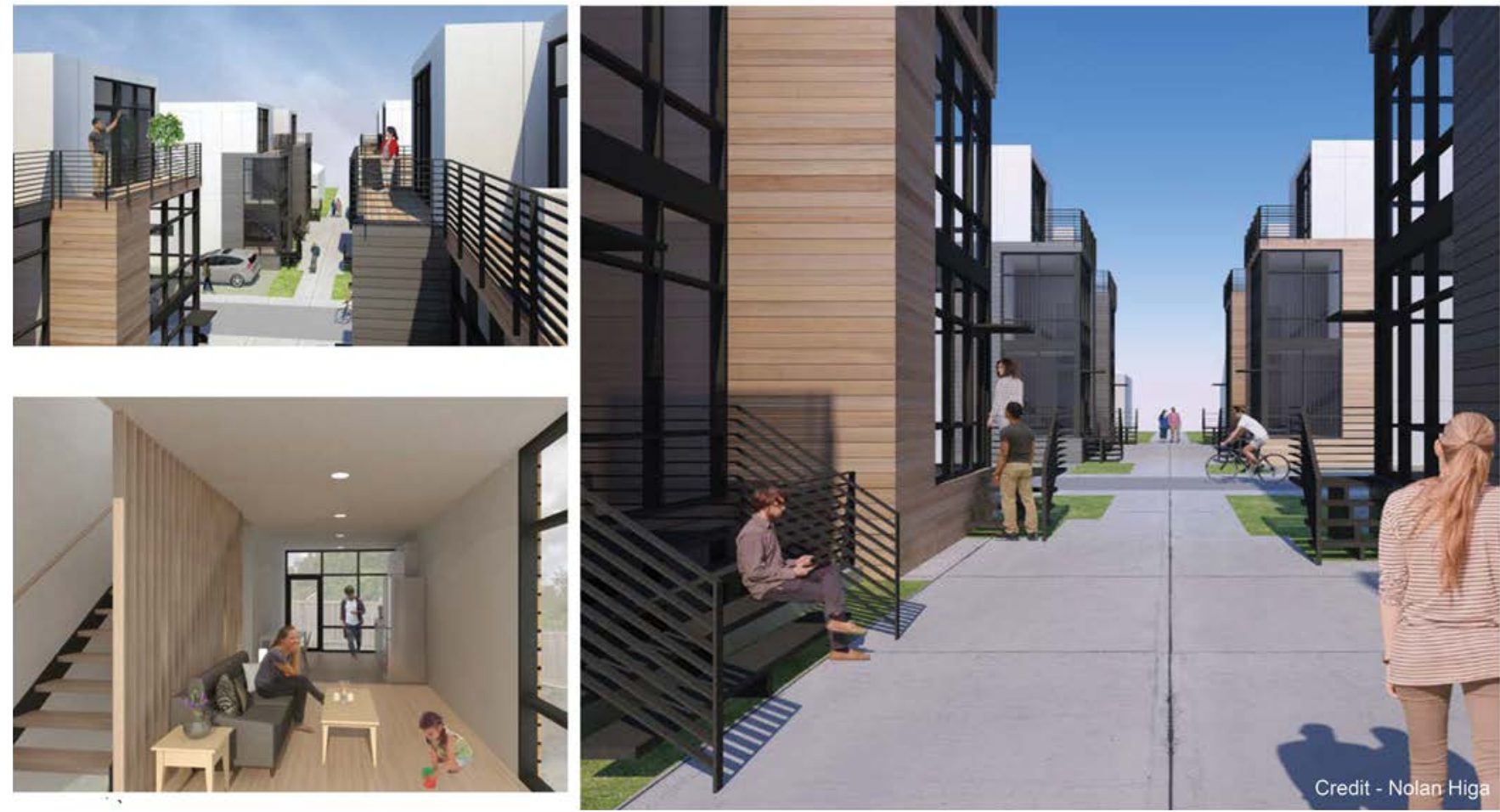
on specific parcels with a focus on prototypical development strategies. The block end development includes row houses with small roof gardens, stoops and lower level accessory dwelling units. A corner commercial space enhances walkability, creates a neighborhood destination and turns the corner to engage the newly activated alley. Alley activation strategies include a prototype small footprint infill building in rear yards with four stacked two bedroom flats each with its own open space enfronting the pedestrian friendly shared space of the alley. The pedestrian through block connection, or mews, enhances neighborhood walkability while quintupling the opportunities for home ownership through small row houses each with its own roof deck and modest rear yard.

Several miles east of Bitter Lake, the Wedgwood neighborhood also consists of relatively large lots on blocks with limited sidewalk infrastructure. In contrast to Bitter Lake, Wedgwood contains few alleys and, instead, a mature, coniferous tree canopy occupies the heart of most blocks. Displacement risk is low as residents are more affluent and there is very little diversity of households or housing types. To preserve tree canopy and introduce housing and income diversity, one proposal replaces an existing single-family dwelling with a co-living development of slightly larger scale providing a home for more than 20 unrelated adults with shared amenities and front and rear gardens. Structured as a limited equity cooperative, the project would provide housing stability and access to the housing market for younger adults as a step toward longer term home ownership.

In southeast Seattle, the traditionally affordable Othello neighborhood is among the most racially diverse in the U.S. Well within the walkshed of a light rail transit stop, the neighborhood has experienced displacement pressures for more than a decade. As in Bitter Lake, this concern is addressed through the retention of existing housing stock and the development of a variety of housing types along its alleys. In one proposal affordability is advanced through the deployment of a prefabricated system of flexible modular units in rear yards to create new alley oriented garden communities with roof decks, balconies and shared open spaces. Pre-fabrication also provides increased predictability of developments costs allowing existing low and moderate income homeowners to retain their property and develop it themselves.

\section{OBSERVATIONS AND IMPACT}

There are several ways in which to measure the success and impact of the coursework outlined above. The research studio and companion seminar are key components of the newly implemented master of architecture curriculum. As such, the individual and collaborative student learning experience within them was critical. Based upon the level of engagement, quality of student work and anonymous student evaluation of both courses, they were generally a success. The most common critique was that the complexity of issues being addressed coupled with the demands of research and design were unreasonable to accommodate within the constraints of a ten week quarter and that two quarters would have been more appropriate. This is currently not an option within the curriculum but is something that should be considered as it evolves.

The studio and seminar worked in collaboration with the Seattle Planning Commission to advance the strategies outlined in its "Neighborhoods for All" report. Roughly half of the commission, including the Executive Director and Chair, directly engaged with the coursework through design reviews and seminar presentations. These consisted primarily of commissioners with architecture and planning expertise who were able to decipher design drawings and diagrams. The intention was for the entire commission to be engaged with a major event at quarter's end but, as outlined below, this proved to be impossible.

A very tangible goal is to influence Seattle's single-family zoning policy in the next major update to its comprehensive plan in 2024. This is a politically contentious issue and, as such, the strategic introduction and socialization of approaches that challenge the status quo is essential. To this end, the term was to conclude with a major public presentation, panel discussion and reception/review with an anticipated 150-200 attendees including elected officials, city staff, planning commissioners, housing advocates and the public at large from Seattle, Portland and Minneapolis both live and remote via Zoom. However, Seattle was host to the first U.S. Coronavirus outbreak on January 21, 2020, and the event was postponed due to a state mandated stay-at-home order at the end of the term. It will be conducted as an online event during the 2020-21 academic year although this will not replace the direct engagement students, policy-makers and the public would have experienced at an in-person event.

The coursework introduced students to the messy fray of public policy debate by engaging them in a national dialogue concerning a challenging and contentious social equity and environmental issue. By providing them with knowledge, data and communications tools they can enter this discourse as effective advocates for change. The studio/seminar also serves as a template for future curricula within the department and beyond in which research and design at the neighborhood, block and building scales are leveraged as tools to foster racial and climate justice at the city scale through public policy change. 

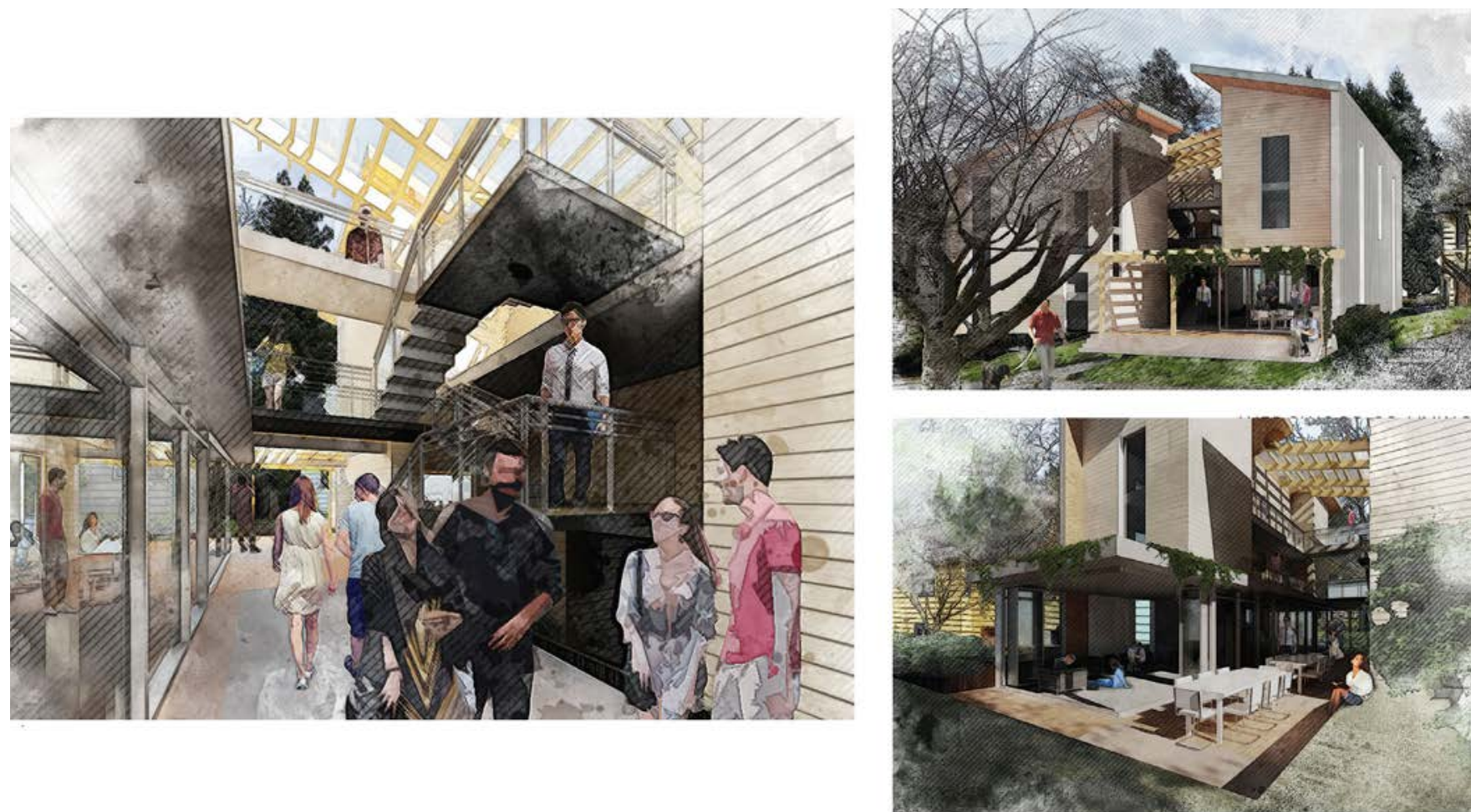

Figure 7. In Wedgwood a co-living project provides entry-level access to home-ownership for more than 20 unrelated adults. Image credit.Steven Moehring
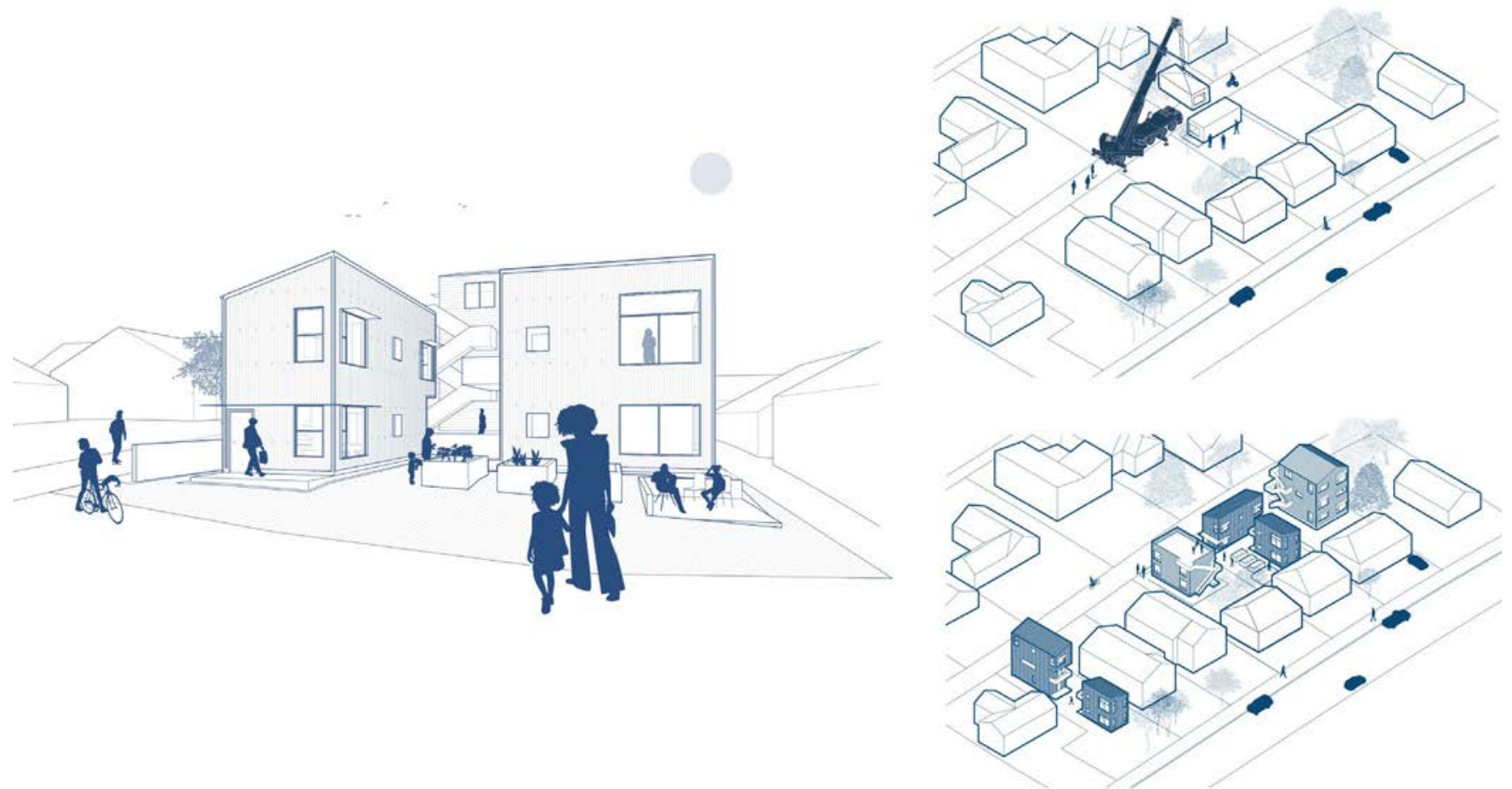

Figure 8. In Othello housing adfordability is advanced by retaining existing housing stock and creating new alley communities from pre-fabricated modular units. Image credit.Jesse Davis 


\section{ENDNOTES}

1. Seattle Fair Growth, https://www.seattlefairgrowth.org/.

2. Dan Bertolet, "Displacement: The Gnawing Injustice at the Heart of Housing Crises", Sightline Institute, August

10, 2016, https://www.sightline.org/2016/08/10/

displacement-the-gnawing-injustice-at-the-heart-of-housing-crises/.

3. National Oceanic and Atmospheric Administration, "Data Snapshot Details: Average Monthly Temperature", Climate.gov, September 6, 2020, https://www.climate.gov/maps-data/data-snapshots/ data-source-average-monthly-temperature.

4. Gene Balk, "Booming Seattle is adding cars just as fast as people", Seattle Times, August 10, 2016, https://www.seattletimes.com/seattle-news/data/ booming-seattle-is-adding-cars-just-as-fast-as-people/.

5. Seattle Planning Commission, "Evolving Seattle's Growth Strategy", Winter 2020, 11, https://www.seattle.gov/Documents/Departments/ SeattlePlanningCommission/GSFinalOnline6.15.20.pdf.

6. Seattle Planning Commission, "About the Planning Commission", https://www. seattle.gov/planningcommission/about-us.

7. Seattle Planning Commission, "Neighborhoods for All: Expanding Housing Opportunity in Seattle's Single-Family Zones, Fall 2018, https://www. seattle.gov/Documents/Departments/SeattlePlanningCommission/ SPCNeighborhoodsForAllFINALdigital2.pdf.

8. Brandon Medina, "U.S. Cities Investing the Most in New Housing [2020 Edition]", Construction Coverage, April 1, 2020, https://constructioncoverage. $\mathrm{com} /$ research/cities-investing-the-most-in-new-housing-2020.

9. Alan J. Stein, "Boeing Bust (1969-1971)", History Link.Org, essay 20923, December 16, 2019, https://historylink.org/File/20923.

10. Seattle Planning Commission, "Neighborhoods for All", 4.

11. Mike Eliason, "This is How You Slow-Walk into a Housing Shortage", Sightline Institute, May 23, 2018, https://www.sightline.org/2018/05/23/ this-is-how-you-slow-walk-into-a-housing-shortage/.

12. Margaret Morales, "Returning Seattle to its Roots in Diverse Housing Types", Sightline Institute, March 1, 2017, https://www.sightline.org/2017/03/01/ returning-seattle-to-its-roots-in-diverse-housing-types/.

13. Seattle Planning Commission, "Evolving Seattle's Growth Strategy", 3.

14. Seattle Planning Commission, "Evolving Seattle's Growth Strategy", 7.

15. C. Lowell Harriss, History and Policies of the Home Owners' Loan Corporation, (Cambridge, MA, National Bureau of Economic Research, 1951), 7-13.

16. Richard Rothstein, The Color of Law, (New York, Liveright, 2017), 63-64.

17. Rothstein, The Color of Law, 48-50.

18. Seattle Planning Commission, "Neighborhoods for All", 17.

19. Emily Badger and Quoctrung Bui, "Cities Start to Question an American Ideal: A House With a Yard on Every Lot" New York Times, June 18, 2019, https://www. nytimes.com/interactive/2019/06/18/upshot/cities-across-america-questionsingle-family-zoning.html.

20. Tracy Jan, "Redlining was banned 50 years ago. It's still hurting minorities today.", Washington Post, March 28, 2018, https:// www.washingtonpost.com/news/wonk/wp/2018/03/28/ redlining-was-banned-50-years-ago-its-still-hurting-minorities-today/.

21. Seattle Planning Commission, "Neighborhoods for All", 24.

22. Seattle Planning Commission, "Neighborhoods for All", 14.

23. Seattle Planning Commission, "Neighborhoods for All", 15.

24. Seattle Planning Commission, "Neighborhoods for All", 25

25. Seattle Planning Commission, "Neighborhoods for All", 16

26. Seattle Planning Commission, "Neighborhoods for All", 24. 